\title{
Biological activity of des-(B26-B30)-insulinamide and related analogues in rat hepatocyte cultures
}

\author{
H. Hartmann ${ }^{1}$, K. Oberhaus ${ }^{2}$, R.Spahr ${ }^{2}$, D. Brandenburg ${ }^{3}$, W.Creutzfeldt ${ }^{1}$ and I.Probst ${ }^{2}$ \\ ${ }^{1}$ Division of Gastroenterology and Endocrinology, Department of Medicine, ${ }^{2}$ Institute for Biochemistry, University of Göttingen, and \\ ${ }^{3}$ Deutsches Wollforschungsinstitut, Aachen, FRG
}

Summary. Short-term and long-term biological activities werc studied in adult rat hepatocytes cultured in the presence of the insulin analogues des-(B26-B30)-insulinamide, $\left[\mathrm{Tyr}^{\mathrm{B} 25}{ }^{\mathrm{B}}\right.$ des(B26-B30)-insulinamide and $\left[\mathrm{His}^{\mathrm{B} 25}{ }^{\mathrm{B}}\right.$ des-(B26-B30)-insulinamide. When compared to insulin, full potency of des-(B26B30)-insulinamide has been reported in rat adipocytes and an enhanced potency has been reported for the other analogues. Steady state binding characteristics of the analogues to hepatocytes were indistinguishable from those of native insulin with half-maximal binding occurring at concentrations of about $0.8 \mathrm{nmol} / 1$. Half-maximal effects for the stimulation of glycolysis and inhibition of basal and glucagon-activated glycogenolysis required identical concentrations for insulin and all 3 analogues. Induction of the key glycolytic enzymes glu- cokinase and pyruvate kinase as well as the inhibition of glucagon-dependent induction of phosphenolpyruvate carboxykinase also required identical concentrations of insulin and the 3 analogues. These data confirm that in cultured hepatocytes the C-terminal amidation of des-(B26-B30)-insulin results in a molecule with full in vitro potency. In contrast to data obtained in adipocytes, the des-(B26-B30)-insulin-amidated analogues with tyrosine or histidine substitutions at position B25 are equally as potent as native insulin in eliciting biological responses in rat hepatocyte culture.

Key words: Insulin, des-(B26-B30)-insulinamide, $\left[\mathrm{Tyr}^{\mathrm{B} 25}{ }^{3}\right.$ des(B26-B30)insulinamide, $\left[\mathrm{His}^{\mathrm{B} 25}\right]$ des-(B26-B30)-insulinamide, liver metabolism; rat hepatocyte culture.
Natural insulins from different animal species and chemically modified insulin analogues have been used in the past to study the relationship between the structure of the insulin molecule and its actions $[1,2]$. In addition, identification of an abnormal product of the human insulin gene in some diabetic patients demonstrated the critical importance of single amino acid residues particularly for genetic mutations involving positions B24 and B25 [3]. In previous studies, sequential shortening of the seven $\mathrm{C}$-terminal residues of the B-chain resulted in a stepwise reduction of biological potency resulting in $20 \%$ activity for the des-pentapeptide analogue when compared to native insulin [4]. Interestingly, however, des-pentapeptide-(B26-B30)insulinamide in which the charged B25 C-terminal carboxylate was neutralized, showed full in vitro potency [5]. Furthermore, related amidated analogues with tyrosine or histidine substitutions at position $\mathrm{B} 25$, namely $\left[\mathrm{Tyr}^{\mathrm{B} 25}\right]$ des-(B26-B30)-insulinamide and [His ${ }^{\mathrm{B} 25}$ ]des-(B26-B30)-insulinamide demonstrated an enhanced biological activity of 230 and $310 \%$, respectively when compared to native insulin [6]. Until now, biological potency of these analogues has only been evaluated through in vitro stimulation of lipogenesis in rat adipocytes. Since insulin-mediated regulation of liver metabolism contributes significantly to glucose homeostasis [7], the present work investigated the biological activity of these amidated des-pentapeptide analogues of short- and long-term regulatory events using primary cultures of adult rat hepatocytes.

\section{Materials and methods}

\section{Materials}

Chemicals were reagent grade and from commercial sources. Insulin analogues were prepared as described previously $[5,6]$. Enzymes, fetal calf serum and M 199 medium were purchased from Boehringer Mannheim (Mannheim, FRG); bovine scrum albumin, glucagon, porcinc insulin and antibiotics were from Serva (Heidelberg, FRG). Collagenase was obtained from Worthington (Berlin, FRG) and D$\left[\mathrm{C}^{14} \mathrm{C}\right] \mathrm{glucose}$ (specific activity $3.7 \mathrm{mCi} / \mathrm{mmol}$ ) from New England Nuclear (Dreieich, FRG). Mono-iodinated porcine (Tyr-A 14)- ${ }^{125_{1}}$ labelled insulin $(\sim 350 \mu \mathrm{Ci} / \mu \mathrm{g})$ was donated by Eli Lilly (Bad Homburg, FRG). 


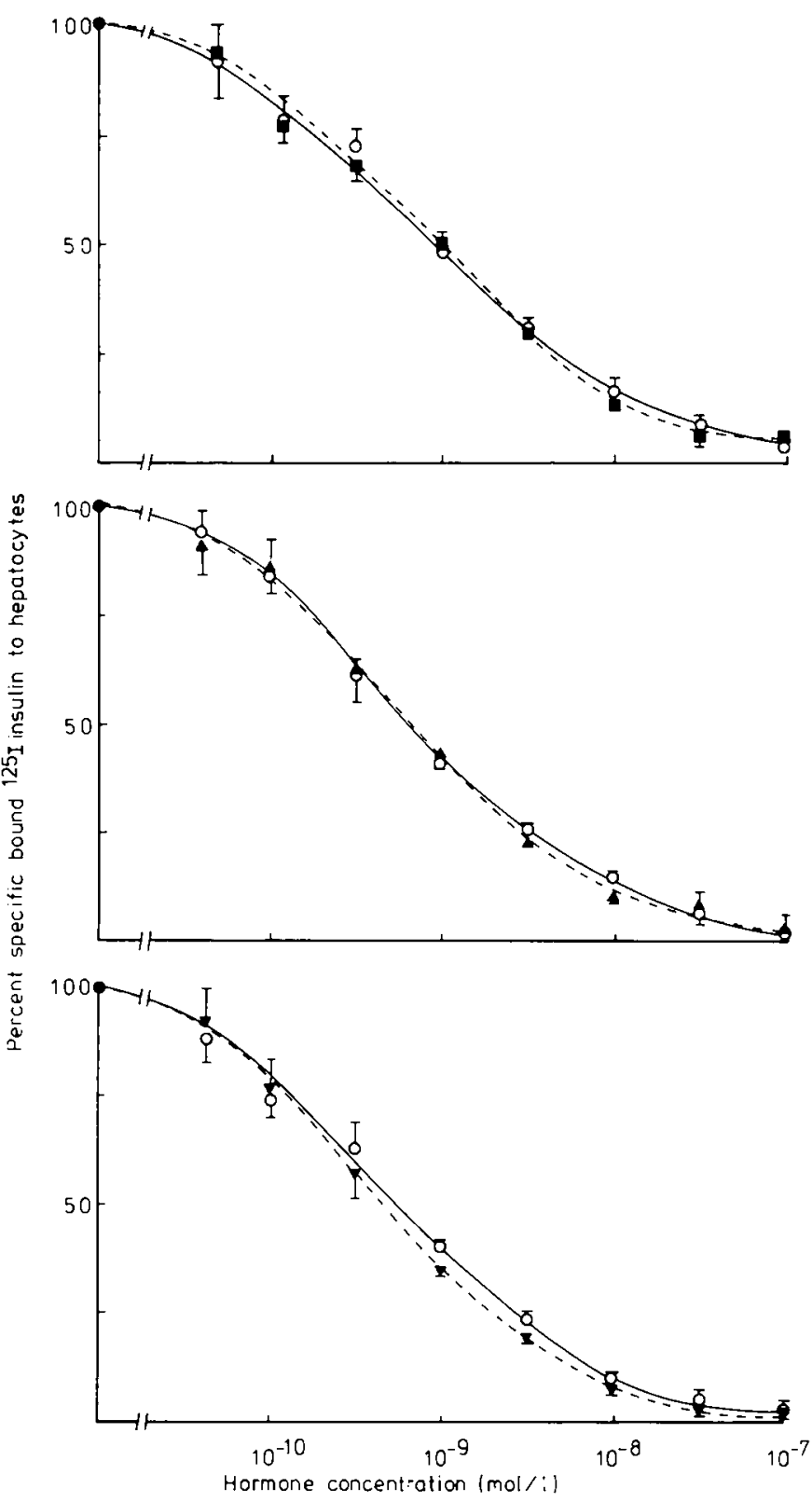

Fig. 1. Binding of insulin and insulin analogues to cultured hepatocytes. Competition binding curves were obtaincd for insulin $(\mathrm{O}-\mathrm{O})$, des-(B26-B30)-insulinamide ( $\left.---{ }^{-}\right)$, [His $\left.{ }^{\mathrm{B} 25}\right]$ des-(B26B30)-insulinamide $\left(\boldsymbol{\Delta}^{---\Delta)}\right.$ and $\left[\mathrm{Tyr}^{\mathrm{B} 25}\right]$ des-(B26-B30)-insulinamide $\left(\boldsymbol{\nabla}-\boldsymbol{\nabla}^{-}\right)$using ${ }^{125}$ I-labelled porcine insulin. Data are means $\pm \mathrm{SD}, n=3$. $100 \%$ specific binding is defined as the difference between cell bound radioactivity (about $10 \%$ of total radioactivity) in the absence of unlabelled ligands and the unspecific binding

\section{Cell culture}

Hepatocytes were isolated with collagenase from livers of fed Wistar rats by a recirculating in situ perfusion technique, as previously described [8]. Cells were suspended in M 199 medium, supplemented with $0.2 \%$ weight $/$ volume $(\mathrm{w} / \mathrm{v})$ bovine serum albumin and cultured on $60-\mathrm{mm}$ Falcon plastic dishes. For the first $3 \mathrm{~h}$ of culture, the medium was also supplemented with $4 \%$ volume/volume $(v / v)$ fetal calf serum. After the first medium change (at $3 \mathrm{~h}, 2,5 \mathrm{ml} / \mathrm{dish}$ ), scrum was omitted. The gas atmosphere contained $5 \%(\mathrm{v} / \mathrm{v}) \mathrm{CO}_{2}, 16 \% \mathrm{O}_{2}$ and $79 \% \mathrm{~N}_{2}$.

\section{Binding studies}

Cells were cultured for $48 \mathrm{~h}$ with dexamethasone $(0.1 \mu \mathrm{mol} / \mathrm{l})$ and insulin $(1 \mathrm{nmol} / \mathrm{l})$. After washing with M 199 medium, binding studies of insulin and analogues were performed according to the method of Fleig et al. [9] in serum-free M 199 medium supplemented with $2 \mathrm{mmol} / \mathrm{l} \mathrm{lac}$ tate and $0.1 \mu \mathrm{mol} / \mathrm{l}$ dexamethasone at $37^{\circ} \mathrm{C}(2 \mathrm{ml} / \mathrm{dish})$. Cells were incubated for $1 \mathrm{~h}$ followed by the addition of ${ }^{125} \mathrm{I}$-insulin $(-0.05 \mathrm{\mu Ci} / \mathrm{dish}$, insulin concentration $10.20 \mathrm{pmol} / \mathrm{l}$ ) with or without various concentrations of unlabelled insulin or the respective analogues. Since steadystate binding occurred between 10 and $20 \mathrm{~min}$ for insulin and the analogues and was maintained for at least $1 \mathrm{~h}$, binding data were obtained from $30 \mathrm{~min}$ incubations. Incubations were terminated by aspirating the medium and rapidly washing $(<10 \mathrm{~s})$ the monolayers five times with ice-cold, phosphate-buffered saline $(140 \mathrm{mmol} / \mathrm{l}$ sodium chloride, $2.6 \mathrm{mmol} / 1$ potassium chloride, $8 \mathrm{mmol} / 1$ disodium hydrogenphosphate, $1.5 \mathrm{mmol} / 1$ potassium dihydrogenphosphate). An aliquot of the medium was analysed for trichloroacetic acid (TCA)-soluble and insoluble radioactivity to correct the amount of free hormone for labelled degradation products. Monolayers were solubilized in $1 \mathrm{ml}$ $0.1 \%$ sodium dodecylsulfate und precipitated with $10 \%$ TCA to correct for cell-associated degraded label. Results were also corrected for unspecific binding (15-20\% of total bound) determined from parallel cultures run in the presence of $10 \mu \mathrm{mol} / 1$ unlabelled insulin. $\mathrm{All}$ binding data were normalized to cellular DNA.

\section{Glycolysis}

Hepatocytes cultured for $48 \mathrm{~h}$ in the presence of dexamethasone $(0.1 \mu \mathrm{mol} / \mathrm{l})$ and insulin $(1 \mathrm{nmol} / \mathrm{l})$ were washed and incubated in insulin-free M 199 medium for $1 \mathrm{~h}$. The medium was then changed $(2 \mathrm{ml} /$ dish $)$ and supplemented with lactate $(2 \mathrm{mmol} / \mathrm{l})$ and $\left[{ }^{14} \mathrm{C}\right] \mathrm{glu}-$ $\operatorname{cose}(\oplus .8 \mu \mathrm{Ci} / \mathrm{dish})$. After a 30 -min preincubation, zcro time medium samples $(130 \mu \mathrm{l})$ were taken and the experiment was started by the addition of insulin or its analogues at the respective concentrations. The incubation was terminated after $3 \mathrm{~h}$ by rapidly aspirating the medium and immersing the dishes in liquid $\mathrm{N}_{2}$. Production of lactate was linear for $240 \mathrm{~min}$ for insulin- and analogue-stimulated cells. $\left[{ }^{14} \mathrm{C}\right] \mathrm{lac}-$ tate produced from $\left[{ }^{14} \mathrm{C}\right.$ ]glucose was separated by ion-exchange chromatography as previously described [10].

\section{Glycogenolysis}

During $24 \mathrm{~h}$ of culture, $\left[\mathrm{U}^{14} \mathrm{C}\right] \mathrm{glucose}(-3 \mu \mathrm{Ci} / \mathrm{dish})$ was incorporated into glycogen in the presence of $20 \mathrm{mmol} / 1$ glucose, $10 \mathrm{nmol} / 1$ insulin and $0.1 \mu \mathrm{mol} / \mathrm{l}$ dexamethasone. The remaining labelled glucose was then removed by 3 successive washings. The medium for the experiments contained $5 \mathrm{mmol} / 1$ glucose, $2 \mathrm{mmol} / \mathrm{l}$ lactate, $0.1 \mu \mathrm{mol} / \mathrm{l}$ dexamethasone and insulin, glucagon or analogues as indicated in the figures. Dishes were allowed $30 \mathrm{~min}$ for preincubation when zcro time medium samples $(130 \mu l)$ were taken. The release of $\left[{ }^{14} \mathrm{C}\right]$ glucose was linear for $120 \mathrm{~min}$. $\left[{ }^{14} \mathrm{C}\right.$ lglucose was separated as described above.

\section{Enzyme induction}

Cells were processed for glucokinase and pyruvate kinase assays using a homogenator Ultra-Turrax (Janke and Kunkel KG, Staufen, FRG) in $100 \mathrm{mmol} / \mathrm{l}$ glycylglycine, $10 \mathrm{mmol} / \mathrm{I} \mathrm{KCl}, 10 \mathrm{mmol} / 1 \mathrm{MgSO}_{4}$, $1 \mathrm{mmol} / 1 \mathrm{EDT} \Lambda$ and $10 \mathrm{mmol} / 12$-mercaptocthanol at $\mathrm{pH} 7.5$. Enzyme activities were detcrmined as described [10], with the extra addition of $0.1 \mathrm{mmol} / 1$ fructose 1.6 bisphosphate in the pyruvate kinase assay. For the phosphoenolpyruvate carboxykinase assay, cells were homogenized in $50 \mathrm{mmol} / 1$ Tris $\mathrm{HCl}$, $\mathrm{pH} 8.1$, containing $0.25 \mathrm{mmol} / 1 \mathrm{MnCl}_{2}$ and $1 \mathrm{mmol} / 1$ dithioery thriol. Enzyme activity was determined according to Seubert and Huth [11] and DNA according to Oliver et al. [12]. 


\section{Results}

\section{Binding to cultured hepatocytes}

Binding characteristics of insulin, des-(B26-B30)-insulinamide and the related analogues were identical as demonstrated in Figure 1 with half-maximal binding occurring at concentrations of about $0.8 \mathrm{nmol} / \mathrm{l}$. About $10 \%$ of the labelled ligand was bound to hepatocytes in the absence of unlabelled insulin or analogues.

\section{Stimulation of glycolysis}

Compared to native insulin, similar maximal as well as half-maximal stimulation of $\left[{ }^{14} \mathrm{C}\right]$ lactate formation from $\left[{ }^{14} \mathrm{C}\right] \mathrm{glucose}$ was observed for the analogues investigated (Fig.2). Half-maximal stimulation was obtained at about $0.8 \mathrm{nmol} / \mathrm{l}$. Compared to cells incubated in the absence of insulin, lactate formation increased from $0.23 \pm 0.14 \mu \mathrm{mol} \cdot \mathrm{h}^{-1} \cdot \mathrm{mg}^{-1}$ DNA to $1.60 \pm 0.65 \mu \mathrm{mol}$. $\mathrm{h}^{1} \cdot \mathrm{mg}^{-1}$ DNA at the maximal effective hormone concentration.

\section{Decrease of basal glycogenolysis}

Insulin and all 3 of the analogues investigated caused an identical maximal and half-maximal decrease of $\left[{ }^{14} \mathrm{C}\right]$ glucose release from $\left[{ }^{14} \mathrm{C}\right] \mathrm{glycogen}$ from $13.85 \pm$ $2.12 \mathrm{\mu mol} \cdot \mathrm{h}^{-1} \cdot \mathrm{mg}^{-1}$ DNA $(100 \%)$ in the absence of insulin to $3.34 \pm 0.66 \mu \mathrm{mol} \cdot \mathrm{h}^{-1} \cdot \mathrm{mg}^{-1}$ DNA $(20 \%)$ at high insulin concentrations $\left(10^{-7} \mathrm{~mol} / 1\right)$. Figure $3 \mathrm{~A}$ depicts the data obtained with des-(B26-B30)-insulinamide.

\section{Inhibition of glucagon-activated glycogenolysis}

When glycogenolysis was activated by glucagon, $\left[{ }^{14} \mathrm{C}\right] \mathrm{glucose}$ release from $\left[{ }^{14} \mathrm{C}\right] \mathrm{glycogen}$ was increased more than two fold compared with basal release rates from $13.85 \pm 2.12 \mu \mathrm{mol} \cdot \mathrm{h}^{1} \cdot \mathrm{mg}^{1}$ DNA to $38.44 \pm 7.13 \mu \mathrm{mol} \cdot \mathrm{h}^{-1} \cdot \mathrm{mg}^{-1}$ DNA (Fig. $3 \mathrm{~B}$ ). Insulin and all 3 analogues suppressed the glucagon-dependent increase completely and further reduced glucose release compared with non-glucagon-activated cells to $<40 \%$. No difference in potency was observed between insulin and all 3 of the investigated analogues as demonstrated for $\left[\mathrm{His}^{\mathrm{B} 25}\right] \mathrm{des}-(\mathrm{B} 26-\mathrm{B} 30)$-insulinamide in Figure 3 B.

\section{Induction of glucokinase and pyruvate kinase}

Incubation of cultured hepatocytes for $48 \mathrm{~h}$ with insulin or one of the analogues at concentrations of $0.1 \mu \mathrm{mol} / 1$
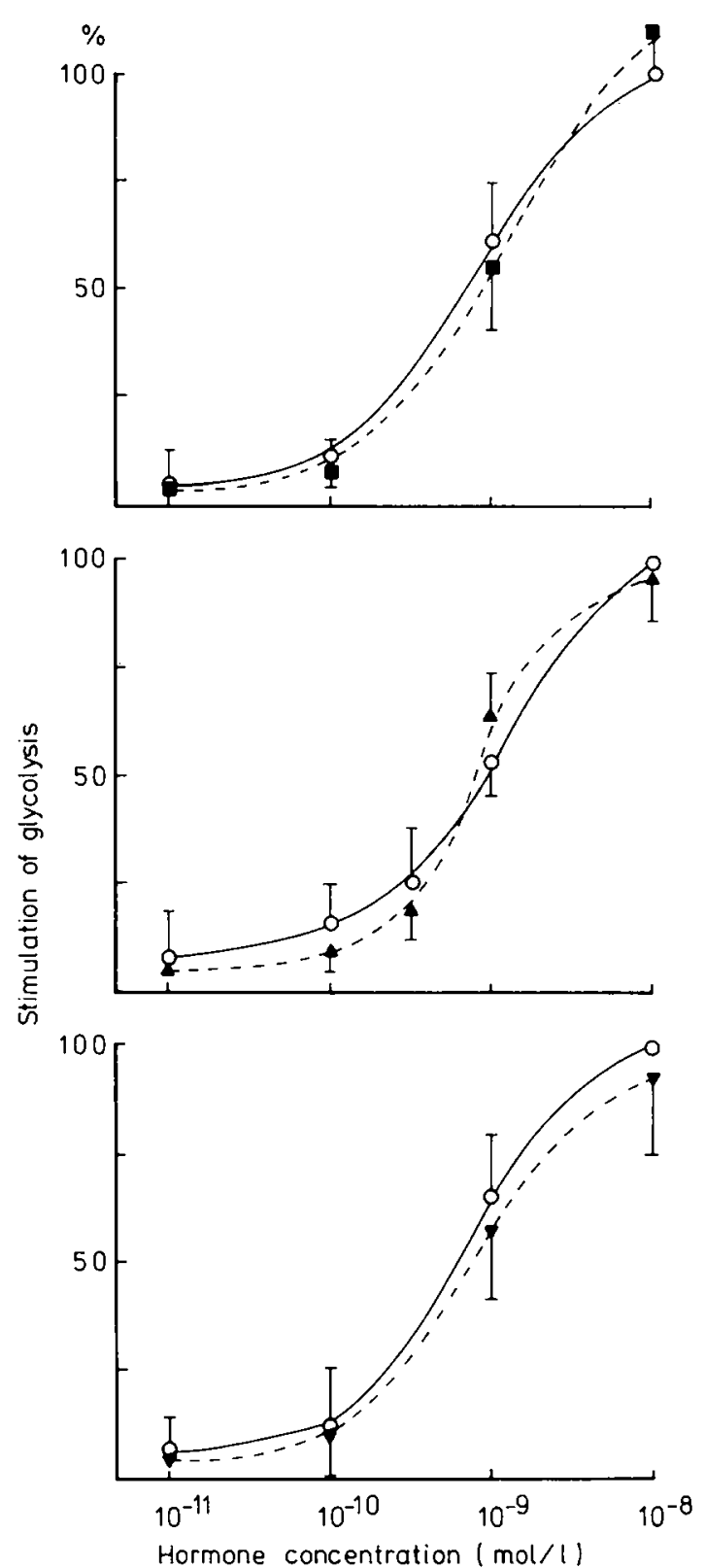

Fig. 2. Stimulation of glycolysis. Cultured hepatocytes were incubated for $3 \mathrm{~h}$ at the respective hormone/analogue concentrations. $100 \%$ stimulation corresponds to lactate formation of cells incubated at the maximal effective insulin concentration of $10^{-8} \mathrm{~mol} / 1$ in individual cell preparations. Data are means $\pm \mathrm{SD}$, in triplicate, $n=3$. Insulin $(\mathrm{O}-\mathrm{O})$; des-(B26-B30)-insulinamide ( $-\cdots)$; [11is ${ }^{\mathrm{B} 25}$ ]des-(B26B30)-insulinamide $\left(\boldsymbol{A}^{-\cdots--A}\right) ; \quad\left[\mathrm{Iyr}^{\mathrm{B} 25}\right]$ des-(B26-B30)-insulinamide $(\boldsymbol{\nabla}-\cdots)$

led to a two-fold increase of glucokinase activity when compared to cells cultured at an insulin concentration of $0.1 \mathrm{nmol} / \mathrm{l}$. Table 1 demonstrates the results obtained with des-(B26-B30)-insulinamide and the tyrosine-substituted analogue. [His ${ }^{\mathrm{B} 25}$ ]des-(B26-B30)-insulinamide was equally effective. The time course of the induction and previous work using specific antibodies under similar conditions showed that the increase in enzyme activity is due to an increase in enzyme protein $[13,14]$. 


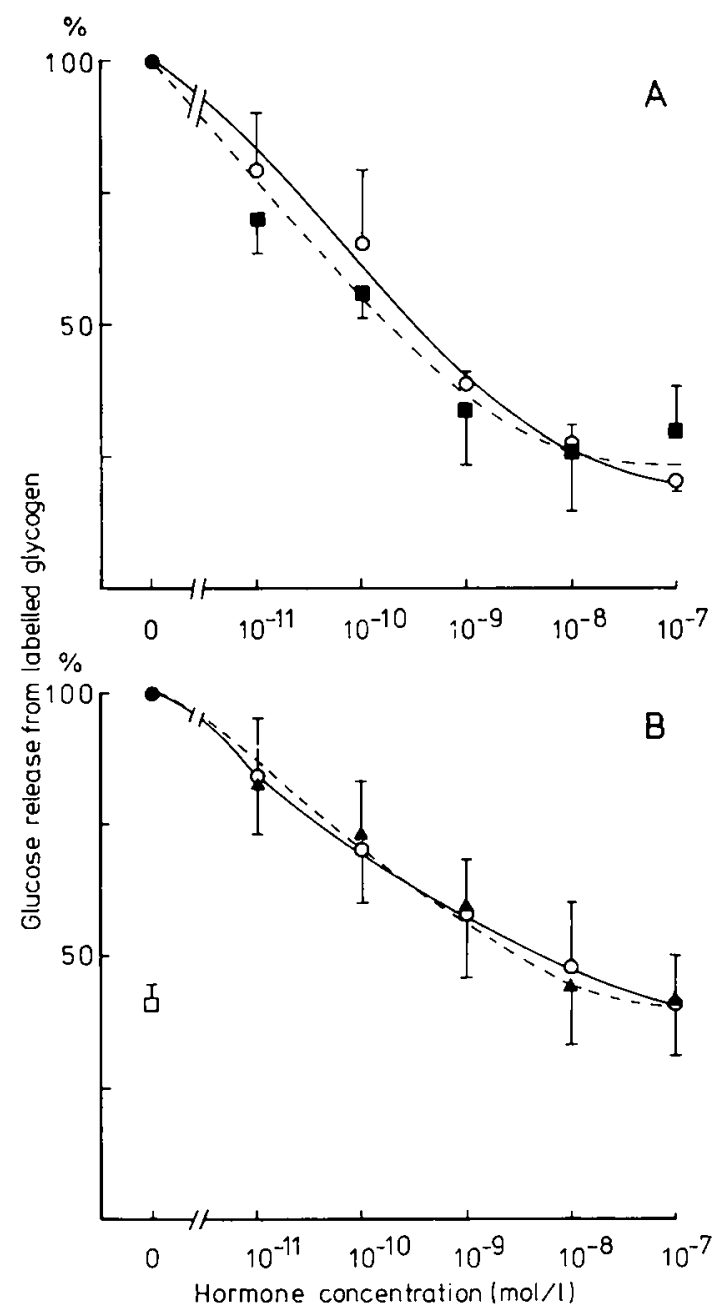

Fig. 3A. Decrease of basal glycogenolysis. Glycogen was prelabelled by incubation of cultures with D-[U- $\left.{ }^{14} \mathrm{C}\right] \mathrm{glucose}$ from 24 to $48 \mathrm{~h}$. Cells were washed and kept at the indicated hormone/analogue concentrations for $90 \mathrm{~min}$. $100 \%$ glucose release corresponds to the amount of glucose released into the medium in the absence of insulin. Data are means \pm SD from 3 cell preparations with triplicates each. Insulin $(\mathrm{O}-\mathrm{O})$; des-(B26-B30)-insulinamide ( $-\cdots-)^{-}$B Inhibition of glucagon-activated glycogenolysis. Glycogen was prelabelled and cells were then incubated for $90 \mathrm{~min}$ in the presence of $0.1 \mathrm{nmol} / \mathrm{glu}$ cagon at the indicated insulin/analogue concentrations. $100 \% \mathrm{glu}$ cose release corresponds to the amount of glucose released into the medium in the absence of insulin. Data are means \pm SD from 3 cell preparations with triplicates each. Insulin $\left(\mathrm{O}_{-}\right)$; $\left[\mathrm{His}^{\mathrm{B} 25}\right] \mathrm{des}$ (B26-B30)-insulinamide ( $\mathbf{-}---\mathbf{A}) ; \square$ indicates cells in the absence of glucagon and insulin

Table 1. Induction of glucokinase and pyruvate kinase in cultured hepatocytes

\begin{tabular}{|c|c|c|}
\hline \multirow{2}{*}{$\begin{array}{l}\text { Condition } \\
\text { insulin/analogue } \\
\left(10^{7} \mathrm{~mol} / 1\right)\end{array}$} & \multicolumn{2}{|c|}{$\begin{array}{l}\text { Enzyme activity } \\
\left(\text { umol } \cdot \mathrm{min}^{-1} \cdot \mathrm{mg}{ }^{1} \mathrm{DNA}\right)\end{array}$} \\
\hline & Glucokinase & Pyruvate kinase \\
\hline Control $^{\mathrm{a}}$ & $0.18 \pm 0.04$ & $2.80 \pm 0.20$ \\
\hline Insulin & $0.32 \pm 0.03$ & $4.19 \pm 0.18$ \\
\hline $\begin{array}{l}\text { Des-(B26-B30)-insulinamide } \\
{\left[\text { Tyr }^{B 25} \text { ]des-(B26-B30)- }\right.}\end{array}$ & $0.30 \pm 0.02$ & $4.52 \pm 0.32$ \\
\hline insulinamide & $0.32 \pm 0.02$ & $4.22 \pm 0.15$ \\
\hline
\end{tabular}

Data are means $\pm S D$ of 6 dishes from 2 different cell preparations.

a insulin concentration $0.1 \mathrm{nmol} / 1$
Inhibition of glucagon-dependent induction of phosphoenolpyruvate carboxykinase

Glucagon, at a concentration of $0.1 \mathrm{nmol} / 1$ increased phosphoenolpyruvate carboxykinase by more than three fold (Fig. 4) after $4 \mathrm{~h}$ of incubation. Previous work suggests that this increase in enzyme activity is due to an increased amount of enzyme protein [15].

Insulin and all 3 analogues antagonized this increase in enzyme activity with identical potency, as demonstrated for $\left[\mathrm{His}^{\mathrm{B25}}\right] \mathrm{des}-(\mathrm{B} 26-\mathrm{B} 30)$-insulinamide in Figure 4.

\section{Discussion}

Des-(B26-B30)-insulinamide and related analogues in which the $\mathrm{C}$-terminal-amidated residue $\mathrm{B} 25$ has been replaced, namely $\left[\mathrm{Tyr}^{\mathrm{B} 25}{ }^{\mathrm{C}}\right.$ des-(B26-B30)-insulinamide and $\left[\right.$ His $\left.^{\mathrm{B} 25}\right]$ des-(B26-B30)-insulinamide have steady-state binding characteristics and short- and long-term metabolic potencies identical to native insulin when evaluated in hepatocyte culture. Previous data on lipogenesis obtained in rat adipocytes, showed an identical potency between des-(B26-B30)-insulinamide and insulin [5]. In addition, an enhanced activity of $160 \%$ has been reported for des-(B26-B30)-insulinamide, when the stimulation of $\left[{ }^{14} \mathrm{C}\right]$ glucose oxidation was evaluated in rat adipocytes [16]. However, binding data for des-(B26-B30)-insulinamide, obtained in isolated canine hepatocytes, were reported to be identical to that of insulin, thus suggesting a discrepancy between binding characteristics and biological potency for this analogue. In the present study metabolic potency of des-(B26-B30)-insulinamide, which to our knowledge has not been previously studied in hepatocytes, is identical to insulin, whether short-term regulatory events like glycolysis or glycogenolysis or long-term metabolic events like induction of regulatory enzymes were studied. Furthermore, the glucagon-antagonistic potency of des-(B26-B30)-insulinamide was no different to that of insulin. Thus, the apparent hepatocyte binding and metabolic potency were indistinguishable. Compared to the non-amidated derivative des-(B26B30)-insulin, for which a biological potency of approximately $20 \%$ was reported when evaluated in rat adipocytes in vitro $[4,17]$, the neutralization of the charged B25 C-terminal carboxylate resulted in a shortened molecule which contained structural and dynamic properties sufficient to elicit full biological potency. These data may contribute to the understanding of the physiological role of dimerisation and negative cooperativity observed for insulin but not the B-chain C-terminal-truncated analogues [18]. Previous data from CD-spectroscopy and gel filtration studies suggested that the des-(B26-B30)-insulinamide is essentially monomeric [5]. Thus, the current data support a recent conclusion derived from in vitro and in vivo studies with the non-amidated despenta- and deshexa analogues about the minor physiological importance of dimerisation [17]. 


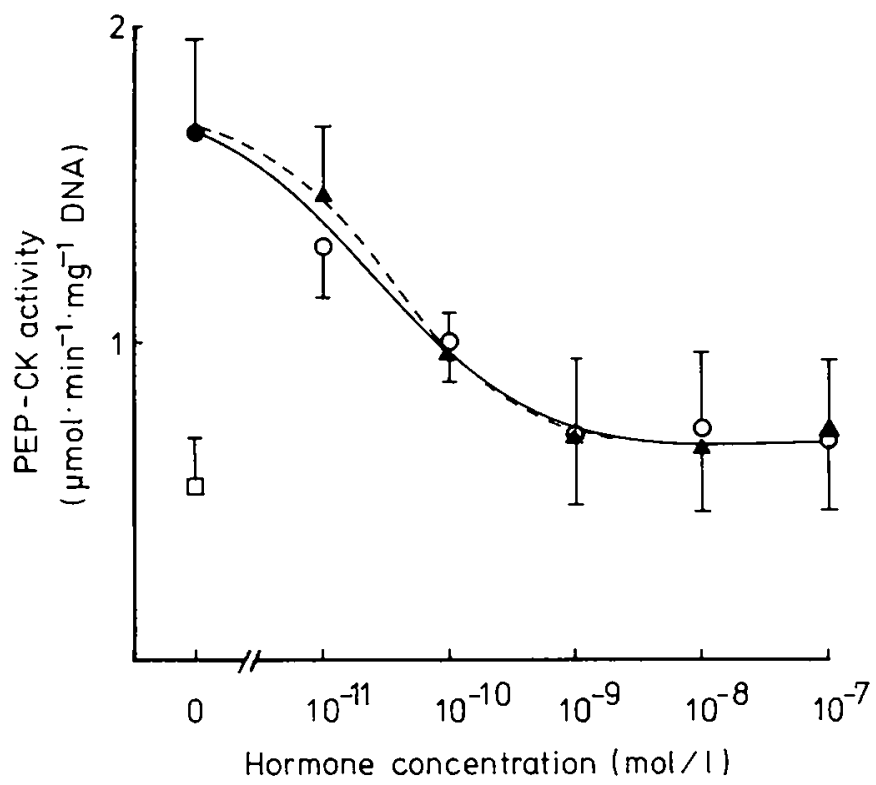

Fig.4. Inhibition of glucagon-dependent induction of phosphoenol pyruvate carboxykinase ( $P E P$-CK). Hepatocytes were cultured for $48 \mathrm{~h}$ and then incubated for $4 \mathrm{~h}$ at a glucagon concentration of $0.1 \mathrm{nmol} / \mathrm{l}$ and at the respective insulin/analogue concentrations. Data are means $\pm \mathrm{SD}$ of 6 dishes at each concentration. Insulin $\left(\mathrm{O}_{-} \mathrm{O}\right)$, $\left[\right.$ His $^{\mathrm{B} 25}$ ]des-(B26-B30)-insulinamide ( $\left.\mathbf{\Delta}^{----\boldsymbol{\Delta}}\right)$, cells without glucagon (ㅁ)

The present investigation of analogues with substitutions of the amidated $\mathrm{B} 25$ residue by tyrosine or histidine did show insulin-like binding characteristics in rat hepatocytes. Previously, $\left[\mathrm{Tyr}^{\mathrm{B} 25}\right]$ des-(B26-B30)insulinamide has been reported to show an enhanced binding affinity to canine hepatocytes of $270 \%$ compared to native insulin [16]. Binding data for the histidine-substituted analogue have not been reported.

The metabolic potencies of these substituted analogues observed in rat hepatocytes are clearly at variance to what has been reported for rat adipocytes in vitro. $\left[\mathrm{Tyr}^{\mathrm{B} 25}\right.$ ]des-(B26-B30)-insulinamide was shown to possess a 2.3-fold increase in activity over insulin in stimulating lipogenesis [6]. Investigators examining the stimulation of glucose oxidation by this analogue, have reported an enhanced potency of 3.3 times that of native insulin [16]. [His $\left.{ }^{\mathrm{B} 25}\right] \mathrm{des}-(\mathrm{B} 26-\mathrm{B} 30)$-insulinamide has been reported to increase the stimulation of lipogenesis, 3.1-fold [6].

It could be speculated that differences in biological potencies for individual analogues in target tissues like liver and adipose tissue might be due to heterogeneity of the insulin receptor $[2,19]$. However, the different methods in the various investigations for the evaluation of binding and metabolic potency should be taken into account.

Acknowledgements. We are grateful to S.Zachmann and K. UnthanFechner for excellent technical assistance and to Dr. M.Casaretto and Dr. M.Spoden for synthesis of the analogues. This work is supported by grant Ha 1498/1-1 and the SFB 111 "Diabetesforschung", Iüsseldorf, from the Deutsche Forschungsgemeinschaft, Bonn-Bad Godesberg, FRG.

\section{References}

1. Brandenburg D, Saunders DJ, Schüttler $\Lambda$ (1983) Pancreatic hormones. In: Jones JH (cd) Amino acids, peptides and proteins: specialist pcriodical reports of the Chemical Society, Vol.11. The Chemical Society, London, pp 461-476

2. Gammeltoft S (1984) Insulin receptors: binding kinetics and structure-function relationship of insulin. Physiol Rev 64: 1321-1378

3. Tager HS (1984) Abnormal products of the human insulin gene. Diabetes 33: 693-699

4. Gattner H-G (1975) Darstellung und Eigenschaften von Des-Pentapeptid (B26-30)-Rinderinsulin. Hoppe-Seyler's Z Physiol Chem 356: $1397-1404$

5. Fischer WH, Saunders D, Brandenburg D, Wollmer $\Lambda$, Zahn $H$ (1985) A shortened insulin with full in vitro potency. Biol Chem Hoppe-Seyler 366: 521-525

6. Casaretto M, Spoden M, Diaconescu C, Gattner H-G, Zahn H, Brandenburg D, Wollmer A (1987) Shortened insulin with enhanced in vitro potency. Biol Chem Hoppe Seyler 368: 709-716

7. Whitton PD (1981) Hormonal regulation of glycogenolysis. In: Hue L, van de Werve G (eds) Short-term regulation of liver metabolism. Flsevier, Amsterdam, pp 45-62

8. Katz NR, Nauck MA, Wilson PT (1979) Induction of glucokinase by insulin under the permissive action of dexamethasone in primary rat hepatocyte cultures. Biochem Biophys Res Commun 88:23-29

9. Fleig WE, Nöther-Fleig G, Steudter S, Enderle D, Dischuneit H (1985) Regulation of insulin binding and glycogenesis by insulin and dexamethasone in cultured rat hepatocytes. Biochim Biophys Acta 847: 352-361

10. Probst I, Schwartz. P, Jungermann K (1982) Induction in primary culture of "gluconeogenic" and "glycolytic" hepatocytes resembling periportal and perivenous cells. Fur J Biochem 126: 271-278

11. Seubert W, Huth W (1965) On the mechanism of gluconeogenesis and its regulation. II. The mechanism of gluconeogenesis from pyruvatc and fumarate. Biochem Z 343: 176-191

12. Oliver IT, Edwards AM, Pitot HC (1978) Hormonal regulation of phosphoenolpyruvate carboxykinase in primary cultures of adultrat liver parenchymal cells. Eur J Biochem 87: 221-227

13. Spence JT, Merrill MJ, Pitot HC (1981) Role of insulin, glucose, and cyclic GMP in the regulation of glucokinase in cultured hepatocytes. J Biol Chem 256: 1598-1603

14. Noguchi T, Inoue H, Tanaka T (1982) Regulation of rat liver Ltype pyruyate kinase mRNA by insulin and by fructose. Fur $\mathrm{J}$ Biochem 128: 583-588

15. Nauck M, Wölfle D, Katz N, Jungermann K (1981) Modulation of the glucagon-dependent induction of phosphoenol pyruvate carboxykinase and tyrosine aminotransferase by arterial and venous oxygen concentrations in hepatocytc cultures. Eur $\mathbf{J}$ Biochem 119: 657-661

16. Nakagawa SH, Tager HS (1986) Role of the phenylalanine B25 side chain in directing insulin interaction with its receptor. $J$ Biol Chem 261: 7332-7341

17. Cockram CS, Jones RH, Sonksen PH, Tatnell MA, Zhu SQ, Dodson $G(1987)$ An examination of the role of insulin dimerisation and negative cooperativity using the biological properties of the despentapeptide and deshexapeptide insulins. Diabetologia 30:733-738

18. De Meyts P, Van Obberghen E, Roth J, Wollmer A, Brandenburg D (1978) Mapping of the residues responsible for the negative cooperativity of the receptor-binding region of insulin. Nature 273: 504-509

19. Burant CF, Treutelaar MK, Block NE, Besse MG (1986) Structural differences between liver- and muscle derived insulin receptors in rats. J Biol Chem 261: 14361-14364

Received: 3 January 1989

and in revised form: 17 April 1989

Dr. H. Hartmann

Medizinische Universitätsklinik

Robert-Koch-Straße 40

D-3400 Göttingen

FRG 